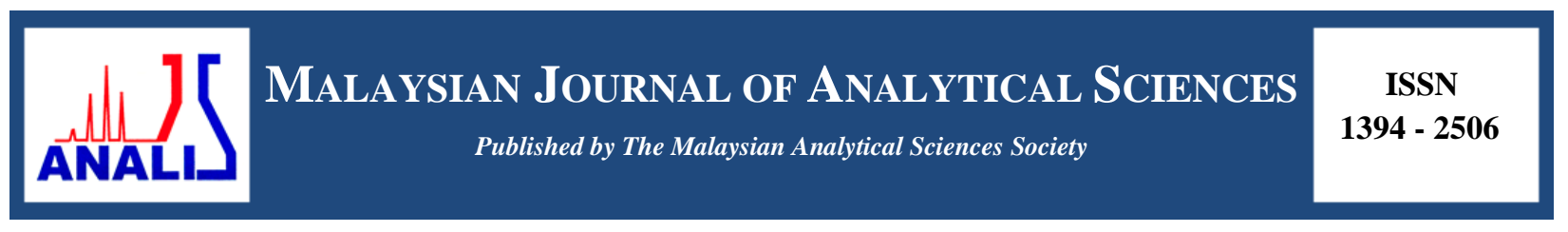

\title{
ELECTROCHEMICAL PROPERTIES OF MESOPOROUS SILICA (SBA-15)-CARBON ELECTRODE
}

\author{
(Ciri Electrokimia Karbon Silica Berliang Meso) \\ Noramira Saad, Mohammad Noor Jalil*, Zainiharyati Mohd Zain, Hamizah Mohd Zaki \\ Faculty of Applied Science, \\ Universiti Teknologi MARA, 40450 Shah Alam, Selangor, Malaysia \\ *Corresponding author: moham423@salam.uitm.edu.my
}

Received: 19 August 2018; Accepted: 14 March 2019

\begin{abstract}
Mesoporous silica is material that possesses the pore sizes between $2 \mathrm{~nm}$ to $50 \mathrm{~nm}$ which had expanded their applications rapidly. In this study, mesostructured SBA-15 was synthesized and characterized then the electrochemical behaviour being analysed to determine the current signal and the impedance of mesoporous silica carbon electrode. The material with pore sizes $5.5 \mathrm{~nm}$ was successfully synthesized by surfactant templating technique, using triblock copolymer pluronic (P123) as directing agent and tetraethyl orthosilicate (TEOS) as silica sources. The synthesized SBA-15 was characterized using X-ray diffraction (XRD), scanning electron microscope (SEM), nitrogen adsorption-desorption and infra-red (IR). Two different electrodes were fabricated which carbon paste electrode (CPE) and hybrid SBA-15 with carbon paste electrode (SBA-15/MCPE) and analysed using cyclic voltammetry $(\mathrm{CV})$ and electrochemical impedance spectroscopy (EIS). The SBA-15/MCPE results better adsorption and enhanced the response signal to $30 \%$ and lower resistance compared to CPE with $179 \Omega$ and $187 \Omega$ respectively due to addition of meso-sites which improved the electron pathway This study demonstrates that mesoporous silica (SBA-15) can be considered as promising material in development of high performance, lightweight and flexible devices in electrochemistry.
\end{abstract}

Keywords: mesoporous silica, SBA-15, electrochemical properties, mesoporous silica-carbon electrode

\section{Abstrak}

Bahan berliang meso ialah bahan yang mempunyai saiz liang antara $2 \mathrm{~nm}$ hingga $50 \mathrm{~nm}$ yang telah dikembangkan aplikasinya secara meluas. Dalam kajian ini, SBA-15 berliang meso telah disintesis dan dicirikan. Setelah itu, sifat elektrokimianya di analisis. Bahan dengan liang bersaiz $5.5 \mathrm{~nm}$ berjaya disintesis melalui teknik templat surfaktan menggunakan triblok ko-polimer pluronic (P123) sebagai agen pengarah dan tetraetil ortosilikat (TEOS) sebagai sumber silica. Bahan yang disintesis dicirikan menggunakan teknik pembelauan sinar-X, mikroskopi imbasan elektron, penyerapan penjerapan nitrogen dan infra merah. Dua elektrod berbeza telah difabrikasikan, iaitu elektrod pes carbon (CPE) dan elektrod yang dimodifikasi (SBA-15/MCPE). Keduadua elektrod yang difabrikasi di analisa dengan menggunakan alat voltametri berkitar dan spektroskopi impedans elektrokimia. SBA-15/MCPE menawarkan penjerapan yang baik dan meningkatkan signal respon sehingga 30\% dan menghasilkan rintangan yang lebih rendah berbanding CPE iaitu masing-masing $179 \Omega$ dan $187 \Omega$. Kajian ini menunjukkan bahawa SBA-15 boleh dianggap sebagai bahan yang berpotensi dalam menghasilkan alat yang berprestaai tinggi, ringan dan flexibel dalam electrokimia.

Kata kunci: silica berliang meso, SBA-15, pencirian elektrokimia, elektrod karbon-silika berliang meso

\section{Introduction}

The discovery of surfactant template silica such MCM-41, MCM-48 and SBA-15 were first reported in early 1990's which lead to whole new class of materials that offer high thermal and mechanical stability [1,2]. Due to continuity 
of mesoporous silica development, the studies regarding their properties are very active [3]. The unique properties of the mesoporous materials such uniform pore size, hexagonal array and large surface area [4] resulting excellent surface enhancement effect [5]. They are important for application in emergent areas such as energy storage in double layer supercapacitors [6], catalytic supports in fuel cell electrodes [7], adsorptions of bulky molecules in liquid phase [8] and improvements of selectivity in electro analysis [9].

Previous research had proved that mesoporous silica carbon paste enhanced the current signal compare to carbon paste electrode $[10,11,12]$. The materials were made from silica which SBA-15 provide 2D pore structure. Apparently, less research has been observed for SBA series compared to similar silica mesostructured, MCM series. The mechanism of electrode's surface during electrical charging is still under debate particularly regarding the effect of silica pore structure with the current signal obtained. In this study, the mesoporous silica (SBA-15) was synthesised than physically characterized. The electrochemical behaviours of the carbon electrode (CPE) and mixture of carbon with mesoporous silica electrode (SBA-15/MCPE) was than characterized using cyclic voltammetry (CV) and impedance spectroscopy (IS).

\section{Chemicals and raw materials}

\section{Materials and Methods}

The chemicals used were analytical grade and purchased from; Tri-block copolymer Pluronic $\mathrm{P} 123, \mathrm{EO}_{20} \mathrm{PO}_{70} \mathrm{EO}_{106}$ (Sigma-Aldrich), tetraethyl orthosilicate, TEOS (98\%, Aldrich), graphite powder $(<20 \mu \mathrm{m}$, Aldrich), paraffin oil (Biobasic), hydrochloric acid, $\mathrm{HCl}\left(36 \%\right.$, Aldrich), Methanol, $\mathrm{CH}_{4} \mathrm{O}$, ethanol, $\mathrm{C}_{2} \mathrm{H}_{6} \mathrm{O}$, deionized water, copper wire, glass tube, epoxy glue.

\section{Instruments}

Synthesized mesoporous silica was characterized by X-ray diffraction (Rigaku D/max-2500), FE-SEM from SUPRA 40 and for $\mathrm{N}_{2}$ adsorption desorption (Micromeritics, ASAP 2060). The electrochemical measurements were carried out using an Auto-lab PGSTAT101 potentiostat which working electrode (CPE and SBA-15/MCPE), reference electrode $(\mathrm{Ag} / \mathrm{AgCl})$ and counter electrode (platinum).

\section{Synthesis of SBA-15 silica}

Mesoporous silica was prepared via surfactant templating technique as described by Sayari et al. [13]. Pluronic P123(4g) was dissolved in deionized water $(30 \mathrm{~mL})$ and $\mathrm{HCl}(2 \mathrm{M}, 120 \mathrm{~mL})$ and stirred in closed container for 20 hours. The TEOS $(8.5 \mathrm{~g})$ was added slowly to the mixture then being stirred vigorously for 15 minutes and kept under static condition for at temperature $35^{\circ} \mathrm{C}$ for 20 hours. Thus, the substance was transferred to oven at $90{ }^{\circ} \mathrm{C}$ for 24 hours. The precipitate obtained was filtered, wash using deionized water and dried for 3 days at $45^{\circ} \mathrm{C}$. obtained silica then calcined at $500{ }^{\circ} \mathrm{C}$ in air for 6 hours.

\section{Electrode fabrication}

Two types of electrodes were prepared for cyclic voltammetry and electrochemical impedance properties as adapted from Hassan et al. [10]. The carbon paste electrode (CPE) was prepared by mixing graphite powder with paraffin oil. The SBA-15 was mixed with graphite powder and bind together using a few drops of paraffin oil to obtain modified carbon paste electrode (SBA-15/MCPE) paste. The pastes were packed tightly into the glass tube's cavity. Implementation of copper wire inside the tube provides electrical contact for the system. Then, bottom surface of the electrodes was polished using smooth paper and washed with deionized water.

\section{Electrochemical measurement}

The electrochemical measurements on electrodes were performed using cyclic voltammetry (CV) at scan rate 0.1 $\mathrm{Vs}^{-1}$ and recorded between $-0.4 \mathrm{~V}-0.6 \mathrm{~V}$. The electrochemical impedance spectroscopy (EIS) measurements were performed using potentiostat at frequencies $1 \mathrm{mHz}$ to $10 \mathrm{MHz}$ [12].

\section{Mesoporous silica structural characterization}

\section{Results and Discussion}

Powder X-ray diffractogram of synthesized mesoporous SBA-15 sample is shown in Figure 1. The diffractogram shows three resolved peaks at $2 \theta \approx 0.9^{\circ}, 1.7^{\circ}$ and $1.9^{\circ}$, corresponding index of (100), (110) and (200) respectively 
which reflected as well-ordered mesoporous silica structured [14]. The presence of peaks can be assigned the diffractions from 2-d symmetry associated with the hexagonal structure [15].

Figure 2 shows FESEM micrographs of synthesized SBA-15 morphologies in 10k $\mathrm{x}$ of magnification. The micrographs show that the production of SBA-15 using P123 as directing agent possessing hexagonal-rod-likeshape to the material as reported [16].

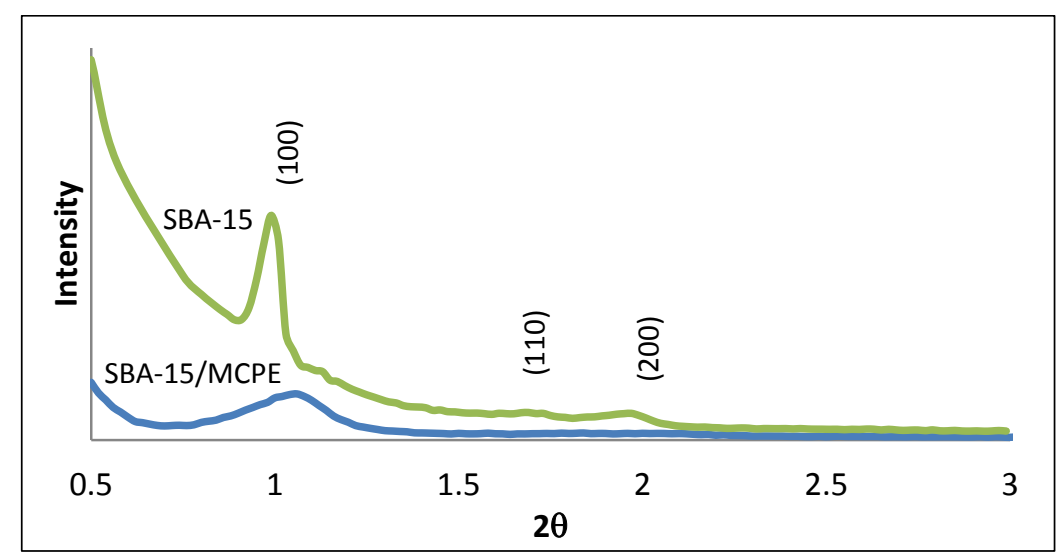

Figure 1. XRD diffraction pattern of calcined SBA-15 silica and mesoporous silica carbon paste (SBA-15/MCPE)
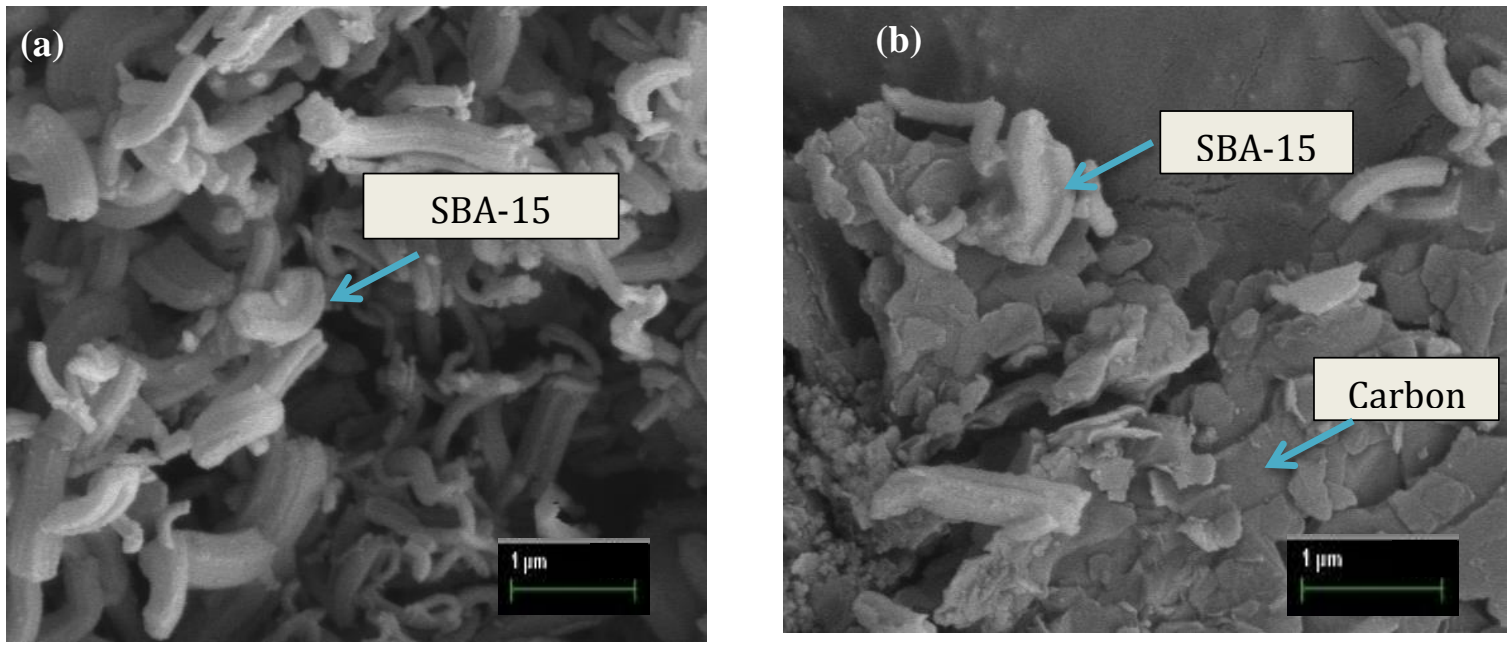

Figure 2. FESEM images of SBA-15 (A) calcined SBA-15 (B) SBA-15/MCPE

The pores structure of prepared mesoporous material was characterized by nitrogen adsorption measurements. The isotherm and pore size distributions of synthesized SBA-15 are shown in Figure 3 and 4. From the isotherm in Figure 3, calcined SBA-15 exhibits type-iv curves according to IUPAC classification [17] with hysteresis loop at relative pressure $\left(\mathrm{P} / \mathrm{P}_{\mathrm{o}}\right)$ at about 0.46 to 0.76 , which indicate mesoporosity. Figure 4 shows the pore size distributions (PSD) curve as determined by BJH method. The PSD show well-defined peaks at pore diameter between $6.0 \mathrm{~nm}$ to $9 \mathrm{~nm}$ for SBA-15 sample. The presence of a low distributed peak between $4 \mathrm{~nm}$ to $6 \mathrm{~nm}$ could be the interconnected pore of SBA-15[18]. The BET surface area, pore volume and pore width of SBA-15 are summarized in Table 1. 
$\begin{array}{ll}\text { Noramira et al: } & \text { ELECTROCHEMICAL PROPERTIES OF MESOPOROUS SILICA (SBA-15)-CARBON } \\ \text { ELECTRODE }\end{array}$

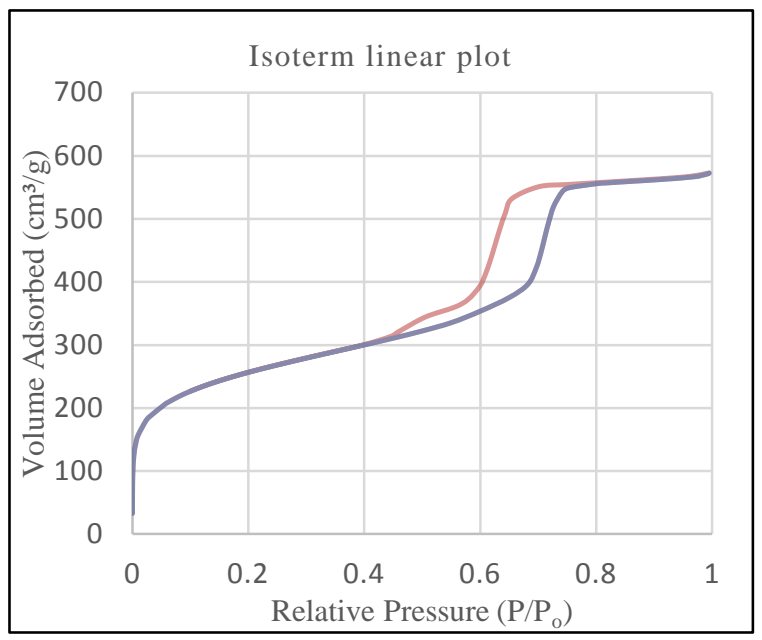

Figure 3. Nitrogen adsorption and desorption isotherms of SBA-15 (calcined at $550^{\circ} \mathrm{C}$ )

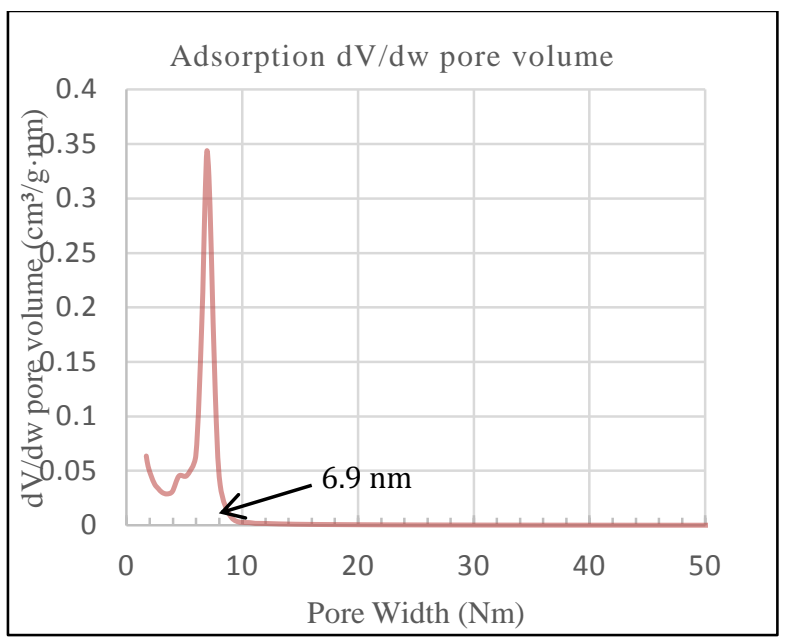

Figure 4. Nitrogen adsorption and desorption isotherms of SBA-15 (calcined at $550{ }^{\circ} \mathrm{C}$ )

Table 1. Pore properties of synthesised SBA- 15 (calcined at $550^{\circ} \mathrm{C}$ )

\begin{tabular}{cccc}
\hline $\begin{array}{c}\mathbf{S}_{\text {BET }}{ }^{(\mathbf{a})} \\
\left(\mathbf{m}^{2} / \mathbf{g}\right)\end{array}$ & $\begin{array}{c}\mathbf{V p}^{(\mathbf{b})} \\
\left(\mathbf{c m}^{3} / \mathbf{g}\right)\end{array}$ & $\begin{array}{c}\mathbf{D p}^{(\mathbf{c})} \\
(\mathbf{n m})\end{array}$ & $\begin{array}{c}\mathbf{D p}^{(\mathbf{d})} \\
(\mathbf{n m})\end{array}$ \\
\hline 913.2626 & 0.8341 & 5.4271 & 4.9021 \\
\hline
\end{tabular}

a Specific surface area determined by BET method,

b Total pore volume,

c Pores diameter $(\mathrm{Dp})$ as determined by BJH from adsorption data

d Pores diameter (Dp) as determined by BJH from desorption data

\section{Electrochemical behaviours study of mesoporous silica}

The electrochemical behaviours were studied by cyclic voltammetry (CV) and electrochemical impedance spectroscopy (EIS). Figure 5 shows the cyclic voltammogram of $5.0 \times 10^{-3} \mathrm{M}$ of potassium ferrocyanide with two 
different electrodes with the oxidation peaks positioned at $0.44 \mathrm{~V}$ and $0.56 \mathrm{~V}$ for SBA-15/MCPE and CPE respectively. As for reduction peaks of SBA-15/MCPE and CPE that positioned at $-0.16 \mathrm{~V}$ and $-0.23 \mathrm{~V}$ indicate the presence of redox process [12]. The voltammogram shows that the electrode with SBA-15 (MCPE) exhibits current enhancement with 0.00029 A compared to $0.00017 \mathrm{~A}$ of CPE. This enhanced the response by $30 \%$ at oxidation peak. The same trend can be observed at the reduction peak.

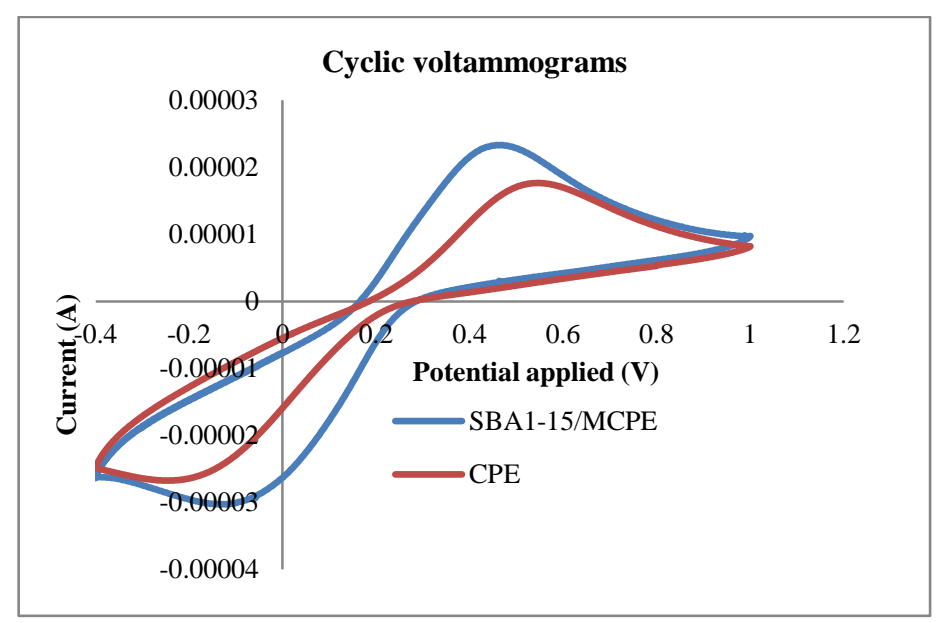

Figure 5. Cyclic voltammograms of $1 \mathrm{mM}$ of $\mathrm{Fe}(\mathrm{CN}) 3-4 /-6$ containing $0.1 \mathrm{M} \mathrm{KCl}$ as supporting electrolyte at $\mathrm{CPE}$ and MCPE

From Figure 6, the Nyquist plot indicates the frequency response of electrode. By fitting the data using Randles circuit (inset), $R_{\mathrm{ct}}$ of CPE and SBA-15/MCPE can be estimated to be $187 \Omega$ and $179 \Omega$ respectively. It is known that silica is non conducting material and suggests that the presence of silica with MCPE had modify surface morphology that attribute of conducting surface and nonconducting surface. This can be considered as selfassembled of micro electrode array as the silica surface contributes to varies spot of conducting and non-conducting site on the electrode surface. Thus, this suggests that SBA-15/MCPE surface promote good electron pathway between electrode and electrolyte. Results low electron-transfer resistance compared to CPE surface [19] as microelectrode properties [20].

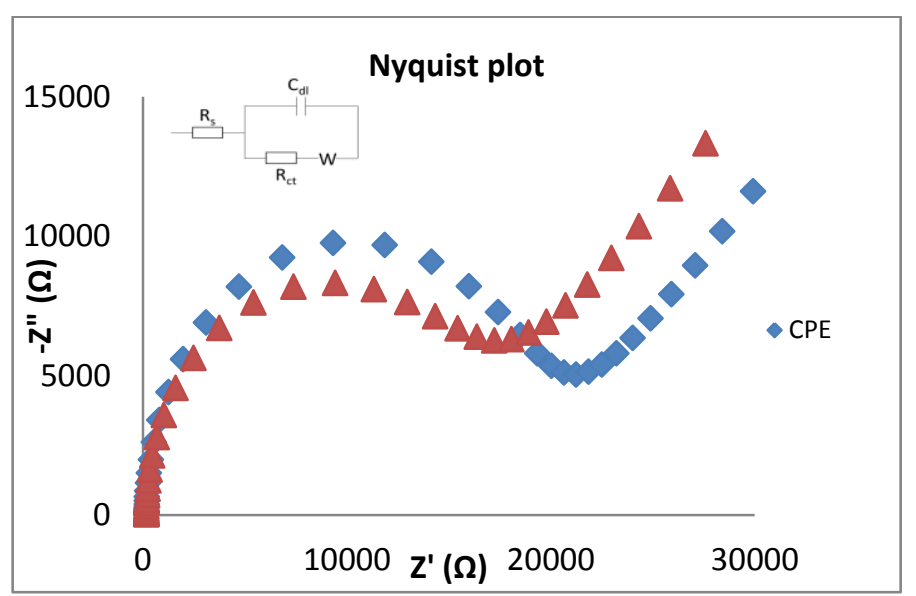

Figure 6. Nyquist plot at $\mathrm{CPE}$ and $\mathrm{MCPE}$ in of $1 \mathrm{mM}$ of $\mathrm{Fe}(\mathrm{CN}) 3-4 /-6$ containing $0.1 \mathrm{M} \mathrm{KCl}$ as supporting electrolyte 


\section{Noramira et al: ELECTROCHEMICAL PROPERTIES OF MESOPOROUS SILICA (SBA-15)-CARBON ELECTRODE}

\section{Conclusion}

The mesoporous material was successfully synthesized with $5.5 \mathrm{~nm}$ pore size. Electrochemical study indicates that MCPE/SBA-15 result higher current by $30 \%$ and lower resistance compared to CPE with $187 \Omega$ and $179 \Omega$ respectively. From the results obtained, the SBA-15/MCPE which combined SBA-15 with carbon shows improvement in electrochemical behaviours due to unique characteristics of mesoporous silica material which prohibit uniform pore, large pores size and high pore volume. Higher fraction of mesopores in the carbon paste (MCPE) mixture promote higher current densities on the surface. This provides many favourable sites for electron transfer [21,22] and shows a smaller resistance $(179 \Omega)$ with respect to mainly carbons paste [23] as microelectrodes properties. For further study, different pore structure silica as SBA-16 and the different composition of silica may be use to study the contribution towards the electrochemical behaviours.

\section{Acknowledgement}

The authors gratefully acknowledged the financial support from Research Management Centre (RMI), Universiti Teknologi MARA (UiTM) under the Supervision Intensive Grant (600-IRMI/MYRA 5/3/GIP(05/2017), NonDestructive Biomedical and Pharmaceutical Research Centre of Faculty Farmacy, Universiti Teknologi MARA Puncak Alam and Institute of Science (Centre of Advanced Materials) Universiti Teknologi MARA Shah Alam for the facilities.

\section{References}

1. Prub, T., Macquarrie, D. J. and Clark, J. H. (2004). Cobalt-acetato complexes immobilised on PYPAorganomodified silica: A case study of different ways of immobilisation. Journal of Molecular Catalysis A: Chemical, 211(1-2): 209 - 217.

2. Guo, W., Luo, G. S. and Wang, Y. J. (2004). A new emulsion method to synthesize well-defined mesoporous particles. Journal of Colloid and Interface Science, 271(2): 400 - 406.

3. Cesarino, I., Marino, G., Matos, J. D. R. and Cavalheiro, É. T. (2007). Using the organofunctionalised SBA-15 nanostructured silica as a carbon paste electrode modifier: determination of cadmium ions by differential anodic pulse stripping voltammetry. Journal of the Brazilian Chemical Society, 18(4) 810 -817.

4. Hoffmann, F., Cornelius, M., Morell, J. and Fröba, M. (2006). Silica- based mesoporous organic-inorganic hybrid materials. Angewandte Chemie International Edition, 45(20): 3216 - 3251.

5. Sun, D., Xie, X. and Zhang, H. (2010). Surface effects of mesoporous silica modified electrode and application in electrochemical detection of dopamine. Colloids and Surfaces B: Biointerfaces, 75(1): 88 - 92.

6. Matos, J. R., Mercuri, L. P., Kruk, M. and Jaroniec, M. (2001). Toward the synthesis of extra-large-pore MCM41 analogues. Chemistry of Materials, 13(5): 1726 - 1731.

7. Fuertes, A. B. (2004). Synthesis of ordered nanoporous carbons of tuneable mesopore size by templating SBA15 silica materials. Microporous and Mesoporous Materials, 67(2-3): 273 - 281.

8. Shan, Y., \& Gao, L. (2007). Formation and characterization of multi-walled carbon nanotubes/Co3O4 nanocomposites for supercapacitors. Materials Chemistry and Physics, 103(2-3): 206-210.

9. Marino, G., Bergamini, M. F., Teixeira, M. F. and Cavalheiro, E. T. (2003). Evaluation of a carbon paste electrode modified with organofunctionalized amorphous silica in the cadmium determination in a differential pulse anodic stripping voltammetric procedure. Talanta, 59(5): $1021-1028$.

10. Hassan, H. M., Ab Rahman, N. B. and Jalil, M. N. (2016). Mesoporous silica electrochemical sensors for the detection of ascorbic acid and uric acid. Malaysian Journal of Analytical Sciences, 20(2): 351 - 357.

11. Ndamanisha, J. C. and Guo, L. P. (2012). Ordered mesoporous carbon for electrochemical sensing: A review. Analytica Chimica Acta, 747: $19-28$.

12. Lufrano, F. and Staiti, P. (2010). Mesoporous carbon materials as electrodes for electrochemical supercapacitors. International Journal Electrochemical Sciences, 5: 903 - 916.

13. Sayari, A., Han, B. H. and Yang, Y. (2004). Simple synthesis route to monodispersed SBA-15 silica rods. Journal of the American Chemical Society, 126(44): 14348 - 14349.

14. Dos Santos, S. M. L., Nogueira, K. A. B., de Souza Gama, M., Lima, J. D. F., da Silva Júnior, I. J. and de Azevedo, D. C. S. (2013). Synthesis and characterization of ordered mesoporous silica (SBA-15 and SBA-16) for adsorption of biomolecules. Microporous and Mesoporous Materials, 180: 284 - 292. 
15. Lin, C. L., Pang, Y. S., Chao, M. C., Chen, B. C., Lin, H. P., Tang, C. Y. and Lin, C. Y. (2008). Synthesis of SBA-16 and SBA-15 mesoporous silica crystals templated with neutral block copolymer surfactants. Journal of Physics and Chemistry of Solids, 69(2-3): $415-419$.

16. Tadjarodi, A., Jalalat, V. and Zare-Dorabei, R. (2013). Synthesis and characterization of functionalized SBA-15 Mesoporous Silica by N, N-Bis (salicylidene) ethylenediamine Schiff-Base. Journal of Nanostructures, 3(4): $477-482$.

17. Sing, K. S. W., Everett, D. H., Haul, R. A. W., Moscow, L., Pierotti, R. A., Rouquerol, J., and Siemienewska T. (1985). Reporting physisorption data for gas/solid systems with special reference to the determination of surface area and porosity. Pure and Applied Chemistry, 57(4): 603-619.

18. Tadjarodi, A., Jalalat, V. and Zare-Dorabei, R. (2013). Synthesis and characterization of functionalized SBA-15 mesoporous silica by N,N-bis (salicylidene) ethylenediamine Schiff-base. Journal of Nanostructures, 3(4): 477 -482 .

19. Ndamanisha, J. C., Bai, J., Qi, B. and Guo, L. (2009). Application of electrochemical properties of ordered mesoporous carbon to the determination of glutathione and cysteine. Analytical Biochemistry, 386(1): 79 - 84.

20. Daniele, S. and Bragato, C. (2014). From macroelectrodes to microelectrodes: Theory and electrode properties in environmental analysis by electrochemical sensors and biosensors. L. Moretto and K. Kalcher (Editors). Springer: New York.

21. Zhou, M., Guo, J., Guo, L. P. and Bai, J. (2008). Electrochemical sensing platform based on the highly ordered mesoporous carbon- fullerene system. Analytical chemistry, 80(12): $4642-4650$.

22. Zhou, M., Ding, J., Guo, L. P. and Shang, Q. K. (2007). Electrochemical behavior of L-cysteine and its detection at ordered mesoporous carbon-modified glassy carbon electrode. Analytical Chemistry, 79(14): 5328 -5335 .

23. Yoon, S., Lee, J., Hyeon, T. and Oh, S. M. (2000). Electric double- layer capacitor performance of a new mesoporous carbon. Journal of the Electrochemical Society, 147(7): 2507 - 2512. 